\title{
Induction of Chromosomal Aberrations and Growth-Transformation of Lymphoblastoid Cell Lines by Inhibition of Reactive Oxygen Species-Induced Apoptosis with Interleukin-6
}

\author{
Hideaki Miwa, Hiroyuki Kanno, Satoru Munakata, Yumiko Akano, \\ Masafumi Taniwaki, and Katsuyuki Aozasa \\ Department of Pathology (HM, HK, SM, KA), Osaka University Graduate School of Medicine, Suita; and Department \\ of Internal Medicine (YA, MT), Kyoto Prefectural University of Medicine, Kyoto, Japan
}

\begin{abstract}
SUMMARY: Etiological evidence, indicating the relationships between the onset of malignant lymphoma and pre-existing chronic inflammation, has been accumulated. For the autonomous growth of malignant tumor, genetic lesions, such as chromosomal aberrations, amplification of oncogenes, and mutations of genes involved in the cell cycle regulation, must be essential. However, how the inflammation promotes the accumulation of genetic lesions and induces the autonomous growth of lymphoid cells remains unclear. Reactive oxygen species released by polymorphonuclear leukocytes and macrophages are factors causing DNA damage in the foci of inflammation, and thus could play a role in lymphomagenesis. The xanthine/xanthine oxidase $(X / X O D)$ system produces a mixture of hydrogen peroxide and superoxide anion extracellularly, and thus serves as an in vitro source of reactive oxygen species. Cell death of lymphoblastoid cell lines (LCLs) was induced with X/XOD treatment in a dose-dependent manner. DNA fragmentation, which is the characteristic feature of apoptosis, was observed in LCLs at 4-8 hours after X/XOD treatment. Among cytokines such as interleukin-6 (IL-6), IL-10, and interferon- $\gamma$, only pretreatment with IL-6 gave LCLs the resistance to X/XOD-induced cell death in a dose-dependent manner. The proportion of apoptotic cells in $\mathrm{X} / \mathrm{XOD}$-treated LCL culture was decreased with IL-6 pretreatment by quantification with flow cytometric analysis. Treatment of LCLs with IL-6 for 48 hours up-regulated bcl-2 mRNA expression. Furthermore, the LCLs repeatedly treated with X/XOD and cultured with or without IL-6 showed many more structural abnormalities of chromosomes than those without X/XOD treatment. Colony forming efficiency of X/XOD-treated LCLs with IL-6 was significantly higher than those without IL-6, and even relatively higher than LCLs without X/XOD treatment. IL-6 could support the survival of non-neoplastic B cells and accelerate the malignant transformation of B lineage cells in inflammatory lesions. (Lab Invest 2000, 80:725-734).
\end{abstract}

$F$ rom the pathoepidemiological studies on the two $F$ types of malignant lymphoma, including B-cell lymphoma of the thyroid gland developing in patients with Hashimoto's thyroiditis (Kato et al, 1985) and B-cell lymphoma in chronic pyothorax patients (pyothorax-associated lymphoma [PAL]) (luchi et al, 1987 1989), we proposed the concept of malignant lymphoma developing in chronic inflammation (Aozasa, 1992; luchi et al, 1989). Malignant lymphoma of mucosa-associated lymphoid tissue is also included in this category (Aozasa, 1992) because Helicobacter pylori-induced follicular gastritis predisposes to gastric lymphoma (Parsonnet et al, 1994). These lymphomas are exclusively of extranodal origin and B-cell

Received January 27, 2000.

Supported in part by Grants from the Vehicle Racing Commemorative Foundation and the Osaka Cancer Association, and by Grants 08770126, 09670184, 09770148, and 11670212 from the Ministry of Education, Science and Culture, Japan.

Address reprint requests to: Dr. H. Kanno, Department of Tumor Virology, Institute for Genetic Medicine, Hokkaido University, N15 W7, Kita-ku, Sapporo 060-8638, Japan. Fax: 8111717 1128; E-mail: hirokan@med.hokudai.ac.jp nature (luchi et al, 1987; 1989; Kato et al, 1985; Parsonnet et al, 1994). Greiner et al (1997) suggest that stimulatory signals in B-cell differentiation, such as CD40 signaling in combination with interleukin-4 (IL-4), are involved in the development of malignant lymphoma of mucosa-associated lymphoid tissue. On the other hand, the analyses of immunoglobulin heavy chain genes in gastric lymphomas show the antigendependent maturation of lymphoma cells (Bertoni et al, 1997; Hallas et al, 1998). This suggests that the antigen stimulation, such as $H$. pylori infection, is also involved in the development of malignant lymphoma. These two mechanisms contribute to the lymphomagenesis merely through their capacity to promote B-cell growth but cannot explain the induction of autonomous growth by pre-existing inflammation.

For the autonomous growth of malignant lymphoma, genetic lesions, such as chromosomal aberrations, amplification of oncogenes, and mutations of genes involved in the cell cycle regulation, must be essential (Gaidano and Dalla-Favera, 1993). However, how the inflammation promotes the accumulation of genetic lesions and induces the autonomous growth of lymphoid cells remains unclear. Reactive oxygen 
species (ROS) released from polymorphonuclear leukocytes and macrophages are the factors causing DNA damage in the foci of inflammation (Cerutti and Trump, 1991). ROS induce DNA strand breaks in mouse epidermal cells (Muehlematter et al, 1988), chromosomal aberrations in Chinese hamster ovary cells (Weitberg et al, 1983), and malignant transformation of cultured mouse fibroblasts (Zimmerman and Cerutti, 1984; Weitzman et al, 1985). Previous studies have shown that ROS can also cause DNA strand breaks (Carson et al, 1986) and chromosomal aberrations (Duell et al, 1995) in resting peripheral blood lymphocytes or phytohemagglutinin-stimulated lymphocytes. However, the relationship between ROS and malignant transformation of lymphoid cells, which should be of importance in the lymphomagenesis with the background of chronic inflammation, has not been established.

ROS are cytotoxic agents and can induce apoptotic cell death, which is inhibited by the bcl-2 family of apoptosis regulatory genes (Hockenbery et al, 1993). Strong oxidative stimuli induce severe DNA damage, which leads to the apoptotic cell death (Carson et al, 1986); however, relatively weak oxidation of sublethal levels might cause the accumulation of genetic aberrations and finally induce the transformation of cells (Carson et al, 1986). Therefore, the in vitro apoptosisinducing system with ROS in a growing B-cell culture must be useful for the analysis of lymphomagenesis in the inflammatory lesions. Next, we utilized the xanthine/xanthine oxidase (X/XOD) system, which is known to generate highly reactive oxygen compounds, such as hydrogen peroxide $\left(\mathrm{H}_{2} \mathrm{O}_{2}\right)$ and superoxide anion $\left(\mathrm{O}_{2}{ }^{-}\right.$) in vitro (Kellogg and Fridovich, 1975). Reasons for the use of the X/XOD system are as follows: (a) among extracellularly administrated ROS, only $\mathrm{H}_{2} \mathrm{O}_{2}$ can permealize the cell membrane and intracellularly generate hydroxy radical $\mathrm{OH}$, which is the most likely free radical responsible for DNA damage (Schraufstätter et al, 1988); (b) lymphocytes and macrophages, the major infiltrating cell populations in the foci of chronic inflammation, can produce $\mathrm{H}_{2} \mathrm{O}_{2}$ and $\mathrm{O}_{2}{ }^{-}$(Schraufstätter et al, 1988; Whitacre and Cathcart, 1992); and (c) because the X/XOD system is an enzymatic reaction, it gradually generates ROS (Sofuni and Ishidate, 1984), in contrast to the administration of whole amount of $\mathrm{H}_{2} \mathrm{O}_{2}$ at a time.

Some inflammatory cytokines might show inhibitory effects on apoptosis and contribute to the survival of cells. Survival of DNA damaged lymphocytes might accelerate the accumulation of genetic lesion. In addition to the growth-promoting activity on nonneoplastic and neoplastic B cells, IL-6 inhibits apoptosis of neoplastic plasma cells (Schwarze and Hawley, 1995), myeloid leukemic cells (Yonish-Rouach et al, 1991), and even non-neoplastic T-cells (Teague et al, 1997). Furthermore, IL-6 is produced in chronic inflammatory lesions including Hashimoto's thyroiditis and $H$. pylori-induced gastritis from various cell populations, such as lymphocytes, macrophages, endothelial cells, and fibroblasts (Akira et al, 1993; Ando et al, 1998). Thus, in chronic inflammatory lesions IL-6 may also inhibit the ROS-induced apoptosis of nonneoplastic $B$ cells and thus accelerate the accumulation of genetic lesions and subsequent transformation.

In the present study, we showed that X/XOD treatment induced apoptosis in lymphoblastoid cell lines (LCLs) and that the pretreatment of LCLs with IL-6 made cells resistant to ROS-induced apoptosis. Furthermore, the growth characteristics and chromosomal aberrations in LCLs repeatedly treated with X/XOD and cultured with or without IL-6 were examined and compared with those without X/XOD treatment.

\section{Results}

\section{Generation of ROS by X/XOD}

Before analyzing the effects of X/XOD treatment on LCLs, we examined the generation of ROS in the current $X / X O D$ system. The amount of $\mathrm{H}_{2} \mathrm{O}_{2}$ generated with $\mathrm{X} / \mathrm{XOD}$ linearly increased within 30 minutes, then gradually elevated through 3 hours (Fig. 1). The production of $\mathrm{H}_{2} \mathrm{O}_{2}$ in the culture medium was dependent on the concentration of XOD (Fig. 2). X (200 $\mu \mathrm{M})$ and XOD $(1.0 \mathrm{mU} / \mathrm{ml})$ generated $\mathrm{H}_{2} \mathrm{O}_{2}$ at the rate of approximately $0.13 \mu \mathrm{m} / \mathrm{min}$. This amount of $\mathrm{H}_{2} \mathrm{O}_{2}$ can be easily produced by $2 \times 10^{6}$ peripheral blood mononuclear cells (mainly monocytes and lymphocytes) stimulated with phorbol ester (Schraufstätter et al, 1988) or opsonized yeasts (Root et al, 1975).

\section{X/XOD-Induced Apoptosis of LCLs}

Cell death of two LCLs (OS and TTK) was induced by $\mathrm{X} / \mathrm{XOD}$ treatment. We measured the viability of cells with trypan blue dye exclusion and also estimated the number of viable cells by MTT assay. Because the

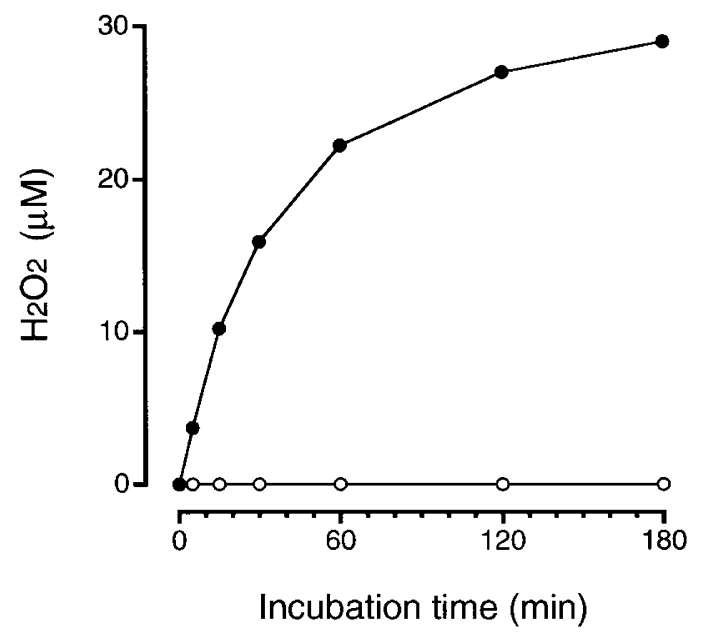

Figure 1.

Time kinetics of $\mathrm{H}_{2} \mathrm{O}_{2}$ production by $\mathrm{X} / \mathrm{XOD}$ system. $\mathrm{X}(200 \mu \mathrm{M})$ was mixed with XOD $(2 \mathrm{mU} / \mathrm{ml} \bullet$; none $\bigcirc)$ in Dulbecco's PBS (DPBS). After incubation at $37^{\circ} \mathrm{C}$ for indicated time periods, the concentration of $\mathrm{H}_{2} \mathrm{O}_{2}$ was measured as described in the "Materials and Methods" section and indicated as $\mathrm{OD}_{480}$. With the standard curve obtained with the known concentrations of $\mathrm{H}_{2} \mathrm{O}_{2}$ in DPBS, the $\mathrm{OD}$ values were converted to the $\mathrm{H}_{2} \mathrm{O}_{2}$ concentration. The mean value of duplicated reaction tubes was indicated. 


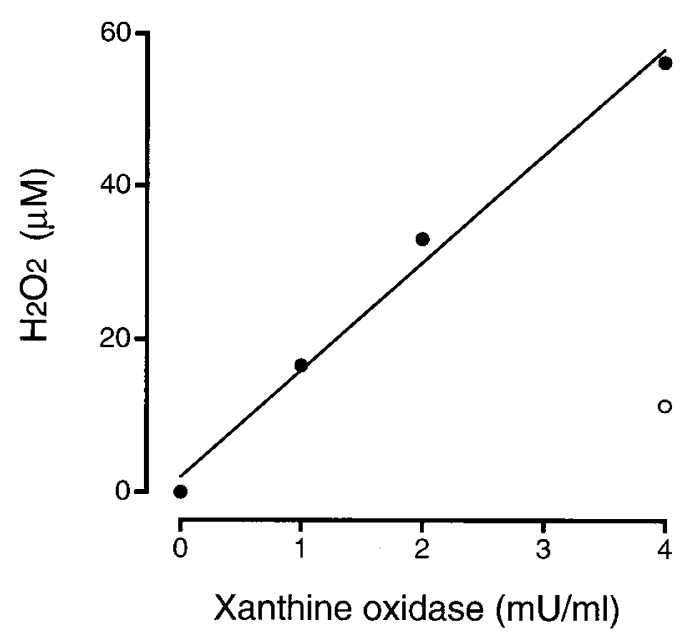

Figure 2.

Dose-dependency in $\mathrm{H}_{2} \mathrm{O}_{2}$ production on the concentration of XOD. X (200 $\mu \mathrm{M}$ ๑; none $\bigcirc$ ) was mixed with XOD at the indicated concentrations in RPMI 1640 medium supplemented with $10 \%$ FCS. After incubation at $37^{\circ} \mathrm{C}$ for 2 hours, the concentration of $\mathrm{H}_{2} \mathrm{O}_{2}$ was measured as described in the "Materials and Methods" section and indicated as $\mathrm{OD}_{480}$. With the standard curve obtained with the known concentration of $\mathrm{H}_{2} \mathrm{O}_{2}$ in the medium supplemented with $\mathrm{FCS}$, the $\mathrm{OD}$ values were converted to the $\mathrm{H}_{2} \mathrm{O}_{2}$ concentration. The mean value of triplicated reaction tubes was indicated.

optical density (OD) values obtained by the 3-(4, 5-dimethyl-2-thiazolyl)-2,5-diphenyl-2H tetrazolium bromide (MTT) assay were correlated well with cell viability (results not shown), we used the MTT assay to estimate cell death in the following experiments. Then, we changed the concentrations of both $\mathrm{X}$ and XOD in culture and estimated the cell death by MTT assay (Fig. 3). The degree of cell death was dependent on the concentrations of both $X$ and XOD. XOD alone induced the death of a small amount of cells in a dose-dependent manner (Fig. 3). Fetal calf serum

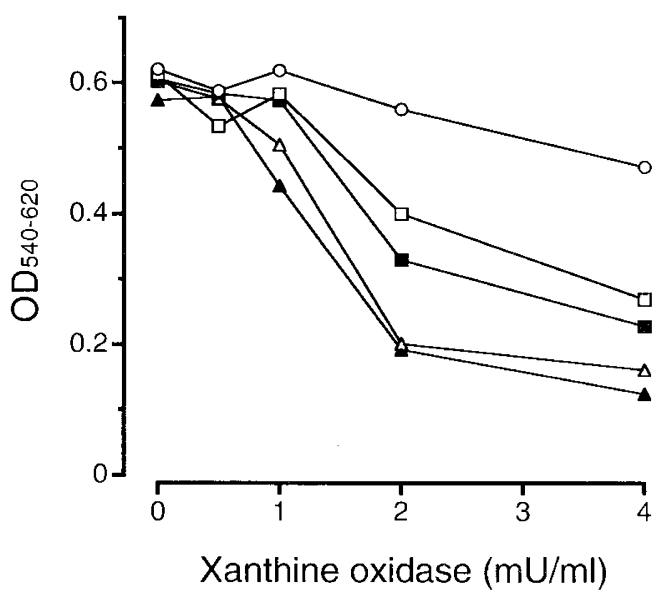

Figure 3.

Effects of the concentration of $X$ and XOD on the death of LCL. OS cells $(3.0 \times$ $10^{4}$ ) were seeded in a well of 96 -well tissue culture plate in $150 \mu$ l of medium in the presence of indicated concentrations of $X$ and $X O D$. After 24 hours incubation, a $50 \mu \mathrm{l}$ of MTT solution was added to each well, and the cells were further incubated for 4 hours. The mean $\mathrm{OD}$ value of quadruplicated wells was indicated. The concentration of $\mathrm{X}$ was $0 \mu \mathrm{M}(\bigcirc), 50 \mu \mathrm{M}(\square), 100 \mu \mathrm{M}(\mathbf{\square}), 200$ $\mu \mathrm{M}(\triangle)$, and $400 \mu \mathrm{M}(\mathbf{\Delta})$.
(FCS) is reported to be a source of substances suitable for enzymatic ROS generation by XOD (Duell et al, 1995; Phillips et al, 1984), and a small amount of ROS is generated as observed in the present study (Fig. 2). At the higher concentration, the effects of $X$ and XOD saturated and a small number of cells even survived (Fig. 3). Furthermore, the cell death induced by X/XOD treatment was completely inhibited in presence of allopurinol at the concentration of $10-100 \mu \mathrm{M}$ (results not shown). This indicates that the cell death caused by X/XOD treatment was mediated by ROS.

To indicate that the cell death induced by X/XOD treatment is apoptosis, DNAs extracted from X/XODtreated LCLs were examined in agarose gel electrophoresis. DNA fragmentation, which is the characteristic feature of apoptosis, was observed in LCLs 4-8 hours after X/XOD treatment (Fig. 4). At these time points, cell death visualized by permeation of trypan blue dye was not obvious. Twenty-four hours after $\mathrm{X} / \mathrm{XOD}$ treatment, when cell death was detected by both dye exclusion test and MTT assay, the DNA ladder in extracted DNA sample disappeared (Fig. 4).

\section{Effects of Cytokines on X/XOD-Induced Apoptosis of LCLs}

Because TTK cells showed results similar to those of OS cells in X/XOD-treated experiments (results not shown), we used only OS cell lines as a representative of LCLs in the following experiments. In preliminary experiments, we first cultured OS cells with or without IL-6, then added X/XOD without washing. However, the apoptosis of OS cells was not induced even in the culture without IL-6. Alternatively, we cultured LCLs in the medium supplemented with an indicated cytokine for 48 hours, washed twice with serum-free medium, and added X/XOD to the culture. In addition to IL-6, interferon- $\gamma$ inhibits the spontaneous apoptosis of B-cell chronic lymphocytic leukemia cells (Buschle et al, 1993), and IL-10 is reported to promote the growth of B cells (Rousset et al, 1992). Among IL-6, IL-10, and interferon- $\gamma$, only pretreatment with IL- 6 induced the resistance to $X / X O D-$ mediated cell death (Fig. 5). The effect of IL-6 on X/XOD-mediated cell death was dose-dependent (Fig. 6). When the duration of IL-6

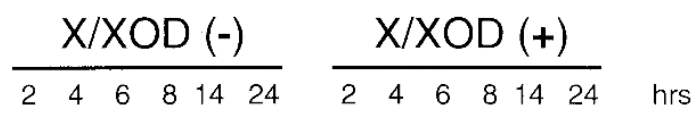

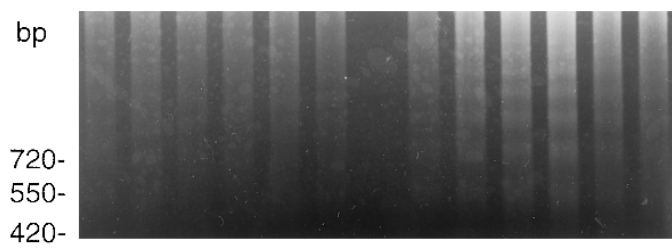

Figure 4.

DNA fragmentation of X/XOD-treated LCLs. OS cells $\left(6 \times 10^{6}\right)$ were cultured in the presence of $X(100 \mu \mathrm{M})$ with or without $\mathrm{XOD}(1 \mathrm{mU} / \mathrm{ml})$ for indicated time periods. Cells were harvested and the fragmented DNAs were extracted. The whole amount of DNA samples (11-22 $\mu \mathrm{g}$ each) were applied to each well and examined in $1.5 \%$ agarose gels. DNA size markers are indicated on the left. LCLs show the DNA ladder from 4-8 hours only after X/XOD treatment. 


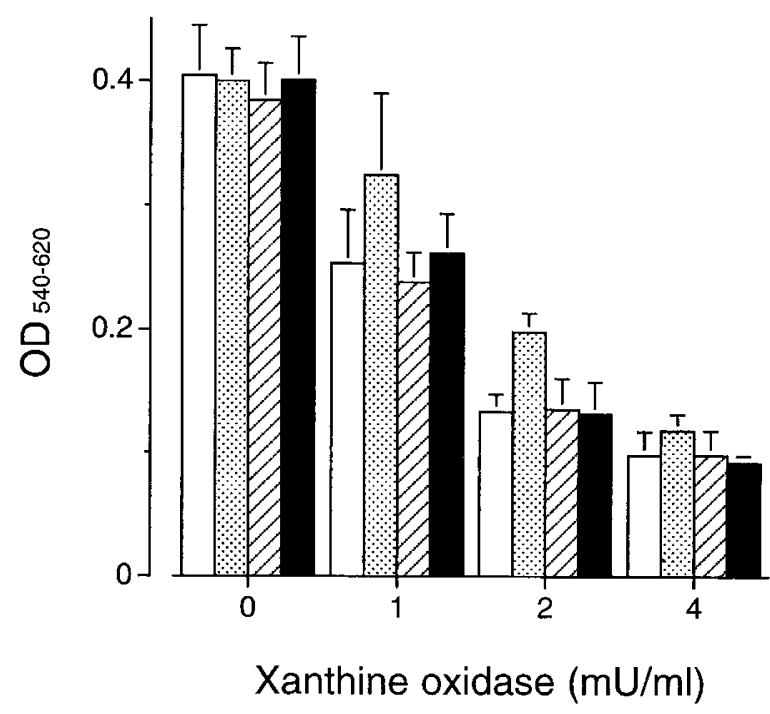

Figure 5 .

Effects of cytokine pretreatment on X/XOD-induced death of LCL. OS cells were incubated with indicated concentrations of cytokines for 48 hours. After washing twice, $3.0 \times 10^{4}$ OS cells were seeded in a well of 96-well tissue culture plate in $150 \mu$ l of medium in the presence of $\mathrm{X}(200 \mu \mathrm{M})$ and indicated concentration of XOD. After 24 hours of incubation, a $50 \mu$ l of MTT solution was added to each well and the cells were further incubated for 4 hours. The mean OD value \pm so of quadruplicated wells was indicated. Open bar. no supplements; dotted bar. IL-6, $50 \mathrm{U} / \mathrm{ml}$; shaded bar. IL-10, $12.5 \mathrm{U} / \mathrm{ml}$; closed bar. IFN- $\gamma, 100 \mathrm{U} / \mathrm{ml}$.

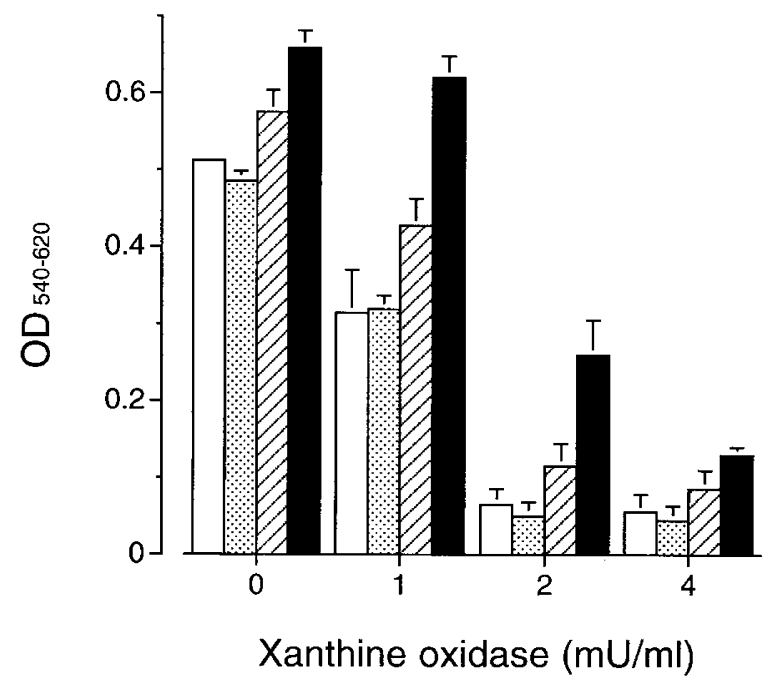

Figure 6.

Dose-dependency in IL-6-mediated inhibition of X/XOD-induced death of LCL. OS cells were incubated with the indicated concentration of human rIL-6 for 48 hours. After washing twice, $3.0 \times 10^{4} \mathrm{OS}$ cells were seeded in a well of 96 -well tissue culture plate in $150 \mu \mathrm{l}$ of medium in the presence of $\mathrm{X}(200 \mu \mathrm{M})$ and indicated concentration of XOD. After 24 hours of incubation, $50 \mu$ of MTT solution was added to each well and the cells were further incubated for 4 hours. The mean $\mathrm{OD}$ value \pm SD of quadruplicated wells was indicated. Open bar. no supplements; dotted bar. IL-6, $1 \mathrm{U} / \mathrm{ml}$; shaded bar. IL-6, $10 \mathrm{U} / \mathrm{ml}$; closed bar. IL-6, $100 \mathrm{U} / \mathrm{ml}$.

pretreatment was changed, the cell death-inhibitory effect was most obvious at 48 hours pretreatment (results not shown). On the other hand, simultaneous treatment of the culture with IL-6 and X/XOD did not show obvious effects on $\mathrm{X} / \mathrm{XOD}$-induced death of
LCLs. Subsequently, we pretreated LCLs with IL-6 for 48 hours, washed the cells, and performed X/XOD treatment in the presence of IL-6. In this case, the apoptosis-inhibitory effects of IL-6, which were rather similar to those in IL-6 pretreatment alone, were observed.

To confirm that IL-6 inhibits apoptosis and does not merely promote the growth of LCLs, we quantified the apoptotic cells with flow cytometric analysis. When the LCL culture was treated with X $(200 \mu \mathrm{m})$ alone, the flow cytometric histograms showed diploid patterns without apoptotic peak and were not affected by IL-6 pretreatment. When the LCLs were treated with 200 $\mu \mathrm{M}$ of $\mathrm{X}$ and $1 \mathrm{mU} / \mathrm{ml}$ of $\mathrm{XOD}$ for 24 hours, $7.7 \%$ of cells formed Sub-G1, apoptotic peak without IL-6 pretreatment. With IL-6 pretreatment for 48 hours at the concentration of $50 \mathrm{U} / \mathrm{ml}, 4.2 \%$ of cells were admitted as apoptosis. The proportion of apoptotic cells in X/XOD-treated LCL culture was decreased with IL-6 pretreatment. When cells were treated with X/XOD for 6 hours, apoptotic peak was small and not affected by IL-6 pretreatment (results not shown).

\section{Increased Expression of bcl-2 by IL-6}

Because the bcl-2 family of apoptosis regulatory genes inhibit the ROS-induced apoptotic cell death (Hockenbery et al, 1993), we examined the bcl-2 expression in IL-6-treated LCLs. Treatment of OS cells with IL-6 at the concentration of $50 \mathrm{U} / \mathrm{ml}$ for 48 hours up-regulated $\mathrm{bcl}-2 \mathrm{mRNA}$ expression detected by Northern blot analysis (Fig. 7).

\section{Repeated X/XOD Treatment of LCLS}

To clarify the role of the apoptosis-inhibitory effects of IL-6 in the transformation of B-lineage cells, we continuously cultured OS cells with or without IL-6 and repeatedly treated the cells with $\mathrm{X} / \mathrm{XOD}$. The cells $(2 \times$ $\left.10^{5} \mathrm{cells} / \mathrm{ml}\right)$ were incubated with $X(200 \mu \mathrm{M})$ and XOD $(0,1,2$, or $4 \mathrm{mU} / \mathrm{ml})$ for 24 hours, and a pair of cultures treated with the same concentration of XOD showing the viabilities of more than $50 \%$ with the pretreatment of IL-6 and less than $50 \%$ without IL- 6 were selected for subsequent passage. The X/XOD-treated cells were continuously passed until the viability of growing cells reached up to $95 \%$; it took 6 to 9 days and 9 to 12 days with and without IL-6, respectively. When both cultures reached a viability of $95 \%$ and a total cell number of $8 \times 10^{6}$ cells, the cells were treated with $X / X O D$ again in the same manner. Thus, one cycle of X/XOD treatment took approximately 2 weeks. This process was repeated six times, and the sublines with and without IL-6 were designated as OSX6 and OSX, respectively. In most of the $X / X O D$ treatments, the cells pretreated with or without IL- 6 showed the differences in the viabilities with $1 \mathrm{mU} / \mathrm{ml}$ of XOD, which was suitable for the subsequent passage, with the exception of the fifth treatment that used $2 \mathrm{mU} / \mathrm{ml}$. The OS cells without $\mathrm{X} / \mathrm{XOD}$ treatment were maintained with and without IL-6 $(100 \mathrm{U} / \mathrm{ml})$ for the same period as that of repeated X/XOD treatment (approx- 


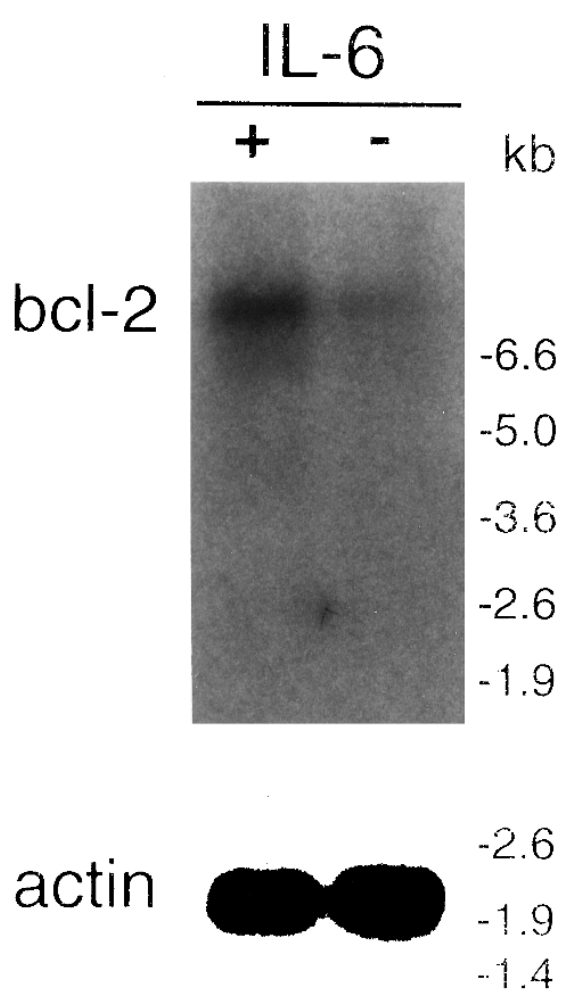

Figure 7.

Northern blot analysis of $b c /-2$ expression in LCLs. OS cells were cultured for 48 hours with $(+)$ or without (minus) human rIL-6 at a concentration of 50 $\mathrm{U} / \mathrm{ml}$ and collected by centrifugation. Five micrograms of mRNA samples were applied to each well, Northern blotted, and hybridized with ${ }^{32} \mathrm{P}$-labeled $\mathrm{bcl}-2$ and actin DNA probes. RNA size markers are indicated on the right. Blots were exposed for 66 hours $(b c l-2)$ and 6 hours (actin) at $-80^{\circ} \mathrm{C}$, respectively.

imately 10 weeks), and designated as OS6 and OSL, respectively. After establishment of these four sublines with indicated treatments, all of the lines were passed every 3 days at the cell density of $1.5 \times 10^{5}$ cells $/ \mathrm{ml}$ without the supplement of IL- 6 and used for the following studies.

\section{Cytogenetic Analysis of OS Sublines}

The structural abnormalities of chromosomes, not merely the numerical changes of chromosomes, were examined as an indicator of genetic aberrations induced in LCLs, and approximately 30 cells of each subline were analyzed. The structural abnormalities of chromosomes in the sublines are summarized in Table 1. The numbers of chromosomal aberrations with structural abnormalities observed in OSX6, OSX, OS6, and OSL were $7,18,5$, and 1, respectively. OSX6 and
OSX exhibited the many chromosomal aberrations with structural abnormalities, and OSX showed many more aberrations than OSX6. OS6 and OSL, without X/XOD treatment, also exhibited structural abnormalities of chromosomes, although the number of chromosomal aberrations were lower than that of OSX6 and OSX (Table 1). The parent, newly recovered OS cells showed only $46 \mathrm{XY}$ normal karyotype and did not exhibit any chromosomal aberrations.

\section{Growth Characteristics of OS Sublines}

The growth characteristics of these OS sublines were examined by MTT assay with various concentrations of FCS ( $1 \%, 2 \%, 5 \%$, and $10 \%)$. In these experiments, the growth of the newly recovered OS cells from frozen stock was also examined. When supplemented with $5 \%$ or $10 \%$ FCS, OS6 and OSL showed the most rapid and the most slow growth among the four sublines, respectively. However, even OSL grew faster than the newly recovered OS parent cells. The growth rates of OSX6 and OSX were nearly the same and were between those of OS6 and OSL (Fig. 8). We also tried the growth assay using medium supplemented with $1 \%$ or $2 \%$ FCS. The growth of the cells was unstable in these experiments, and clear differences in the growth rates among the sublines were not observed, although the four sublines always grew faster than OS parent cells (results not shown).

The colony forming capacity of the sublines in soft agar was also examined in two independent experiments. OSX6 showed the highest cloning efficiency and OSX showed the lowest among the four sublines $(p=0.0003$ in experiment 1 and $p=0.0004$ in experiment 2) (Table 2). OS6 and OSL showed relatively higher cloning efficiency than OSX and the differences from that of OSX6 were not constantly significant (Table 2). The newly recovered OS cells did not form any colonies in both experiments and thus retained the original characteristics of LCLs.

\section{Discussion}

There have been few studies using non-neoplastic B cells to analyze the responsiveness of cells for apoptotic signals. Alterations in the response can be relatively early events during neoplastic transformation and are assumed as an important process in tumorigenesis (Bursch et al, 1984). The nonresting, growing cell culture is suitable for the analysis of regulatory mechanism of apoptosis, especially in relation to the accumulation of genetic lesions of lym-

Table 1. Structural Abnormalities of G-Banded Chromosomes in OS Sublines

\begin{tabular}{ll}
\hline Line & \multicolumn{1}{c}{ Structural Abnormalities } \\
\hline OSX6 & del (16) (q11); $\mathrm{t}(2 ; 20)(\mathrm{q} 37 ; \mathrm{p13}) ;$ ring; 4 mars \\
OSX & del (1) (q21); del (3) (q21); add (1) (p13); add (4) (p14); add (13) (q34); ring; 12 mars \\
OS6 & del (11) (q11); 4 mars \\
OSL & add (3) (q29) \\
OS & None \\
\hline
\end{tabular}




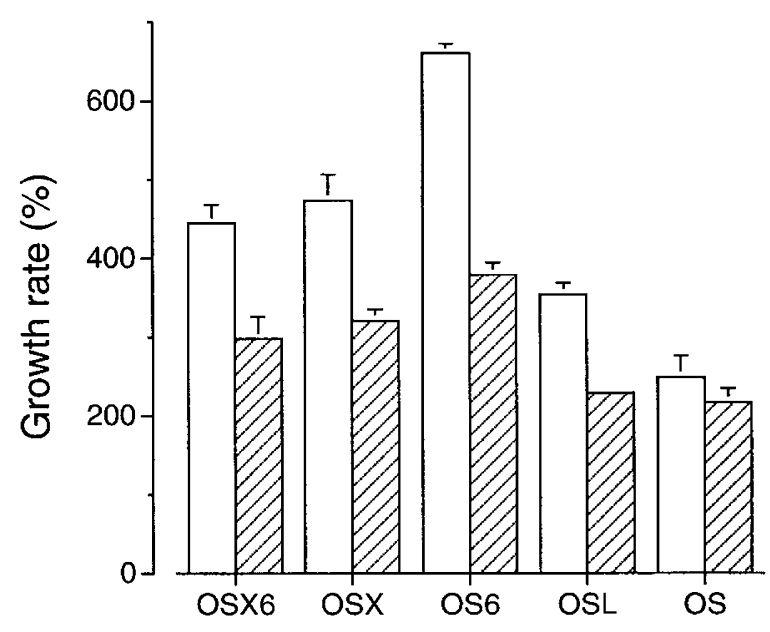

Figure 8.

Growth of OS sublines in medium supplemented with 10\% (open bar) and $5 \%$ (shaded bar) FCS. Cells $\left(1 \times 10^{4}\right)$ were seeded in 96 -well plates. The growth of cells was estimated by the MTT method as described in the "Materials and Methods" section and presented as the proportion of $\mathrm{OD}_{540-620}$ after 72 hours of incubation to that just after seeded in the plates. Results were represented as mean \pm SD of quadruplicate wells. This experiment was repeated three times with similar results in the order of growth rates.

phoid cells in chronic inflammatory foci, where cytokines with growth factor activities may be also secreted. There are two in vitro systems for growing $B$ cells: Epstein-Barr virus (EBV)-transformed LCLs and long-term human B-cell lines supported with CD40mediated signaling in combination with IL-4 (Banchereau et al, 1991). Because PAL, one of the lymphomas developing in chronic inflammation, is an EBV-positive B-cell lymphoma phenotypically resembling LCLs (Kanno et al, 1996), we used the EBV-transformed LCLs as targets for ROS treatment in the present study.

In the present study, we clearly showed that X/XOD treatment induced the apoptosis of LCLs. This mimics the biologic role of ROS released by mononuclear cells in chronic inflammatory lesions. Furthermore, IL-6, at least in part, inhibited the apoptosis of LCLs induced by ROS in a dose-dependent manner. LCLs repeatedly treated with $\mathrm{X} / \mathrm{XOD}$ exhibited many more structural abnormalities of chromosomes than those without $\mathrm{X} / \mathrm{XOD}$ treatment. Although their growth rate and the number of structural abnormalities of chromosomes were not clearly different between the sublines cultured with or without IL-6, the cloning efficiencies of these sublines were significantly different, ie, LCLs treated with $\mathrm{X} / \mathrm{XOD}$ and cultured with IL-6 showed higher cloning efficiency than those without IL-6.

Because IL-6 is an autocrine growth factor of LCLs (Tosato et al, 1990), the possibility that IL-6 merely enhance the growth of surviving cells cannot be completely ruled out in the MTT assay. However, the electrophoresis of extracted DNA and flow-cytometric analysis clearly showed that IL-6 inhibited the apoptosis, not merely promoted the growth of surviving cells. These findings indicate that IL- 6 supported the survival of non-neoplastic B-cells, which should be important in the development of B-cell lymphoma. Fur- thermore, this inhibitory effect of IL- 6 was not obvious on the cells treated with the higher amount of ROS, ie, with a higher concentration of XOD (Fig. 6). This observation may hold true for in vitro conditions. In general, the amount of ROS produced in chronic inflammatory foci would not be as large as that in acute inflammation with massive infiltration of polymorphonuclear leukocytes.

The parent LCLs used in the present study expressed IL-6 mRNA detected by reverse transcriptase-polymerase chain reaction (results not shown) and secreted IL-6 protein into the culture supernatant. The concentration of the IL- 6 protein in the 7 day culture supernatant of parent LCLs was approximately $200 \mathrm{pg} / \mathrm{ml}$, measured by enzyme-linked immunosorbent assay (ELISA) (results not shown). This corresponds to $1 \mathrm{U} / \mathrm{ml}$ of IL-6 activity using human rIL-6 as standard, and is less than the effective dose on the inhibition of ROS-induced apoptosis (Fig. 6). On the other hand, the production of IL-6 in the inflammatory foci in vivo is expected to be much higher. The supernatant of organ culture of mucosal biopsy specimens from an $H$. pylori infected stomach shows the mean IL- 6 concentration of approximately 3 $\mathrm{ng} / \mathrm{ml}$, corresponding to $15 \mathrm{U} / \mathrm{ml}$ (Ando et al, 1998). Thus, the concentration of IL-6 in the local inflammatory foci would be much higher, enough to be effective on apoptosis inhibition. Furthermore, the pleural effusion of pulmonary tuberculosis patients, though not of pyothorax patients, contained high IL-6 activity of up to $100 \mathrm{U} / \mathrm{ml}$ (Yokoyama et al, 1992). Thus, the extracellularly supplied IL-6 from chronic inflammatory lesions in vivo is expected to be sufficiently effective on the inhibition of ROS-induced apoptosis.

Latent membrane protein 1, a product of the EBV gene expressed during latent infection, up-regulates bcl-2 (Henderson et al, 1991). Thus, EBV-transformed $B$ cells (LCLs) are more resistant to apoptosis than normal B cells. Extracellularly administrated IL-6 further up-regulated $b c /-2$ expression in the present system using LCLs. Furthermore, other members of bcl-2 family of apoptosis regulatory genes, such as $b c l-x_{\mathrm{L}}$ (Fang et al, 1995), might be involved in cell survival (Schwarze and Hawley, 1995). The intracellular mechanism of cytokine-induced survival of cells from free radical damage must be an important issue in our understanding of tumorigenesis from inflammation.

Human IL-6 transgenic mice show a massive plasmacytosis (Suematsu et al, 1989) and develop monoclonal plasmacytomas with the chromosomal translocation $t(12 ; 15)$ in a certain genetic background (Suematsu et al, 1992). These reports clearly indicate that IL-6 is important for the polyclonal proliferation of B-lineage cells and that the additional genetic changes must be required for the generation of monoclonal neoplasia. As for the transformation of LCLs, the enforced expression of human IL-6 induced colony formation on soft agar and tumorigenicity in nude mice (Scala et al, 1990). Inoculation of peripheral blood lymphocytes from EBV-seropositive donors into the severe combined immunodeficiency (SCID) mice 
Table 2. Colony Formation in Soft Agar of OS Sublines

\begin{tabular}{rrrcl}
\hline & Lines & No. of Colonies/800 Cells & Cloning efficiency & $p^{*}$ \\
\hline Exp. 1 & OSX6 & 13 & $1.6 \times 10^{-2}$ & - \\
& OSX & 0 & 0 & 0.0003 \\
OS6 & 7 & 5 & $8.8 \times 10^{-3}$ & 0.18 \\
Exp. 2 & OSL & 0 & $6.3 \times 10^{-3}$ & 0.06 \\
& OSX6 & 15 & 0 & 0.0003 \\
& OSX & 1 & $1.9 \times 10^{-2}$ & - \\
& OS6 & 1 & $1.3 \times 10^{-3}$ & 0.0004 \\
& OSL & 9 & $1.3 \times 10^{-3}$ & 0.0004 \\
& OS & 0 & $1.1 \times 10^{-2}$ & 0.22 \\
\hline
\end{tabular}

* To the cloning efficiency of OSX6 in the experiment.

causes EBV-positive lymphoproliferative diseases with or without chromosomal aberrations (Glaser et al, 1993; Rowe et al, 1991). Therefore, we attempted to clarify whether IL-6 promotes the transformation of LCLs in vitro with or without induction of genetic damages. Both OSX6 and OSX exhibited many chromosomal aberrations, but only OSX6 showed a high cloning efficiency. Thus, IL-6 promoted the transformation of ROS-treated LCLs. The exact role of IL-6, however, remains unclear because OSL showed relatively higher cloning efficiency in the current in vitro system.

Among the structural abnormalities of chromosomes in the OS sublines, del (1) (q21) observed in OSX is also found in a PAL cell line, OPL-2 (Kanno et al, 1996). Furthermore, the breakpoint at 1q21 is frequently observed in diffuse large B-cell lymphomas (Cigudosa et al, 1999). The cells with the abnormality at the locus, which is important to lymphomagenesis, might grow up as the apparent malignant clones. In the colony forming assays of the OS sublines, we picked up clones from the four sublines and have established the cloned lines. The detailed analyses of these clones might provide an insight in the different role of cytokines and ROS in the induction of genetic lesions.

In another experiment, we treated LCLs with X/XOD in a shorter interval (less than 2 weeks). In this case, LCLs without IL-6 were treated again with X/XOD before the viability recovered up to $95 \%$, and finally died out, while LCLs cultured with IL-6 survived the same X/XOD treatments. The IL-6-mediated inhibition of apoptosis makes non-neoplastic B cells die hard even in relatively strong inflammatory lesions. Consequently, this mechanism will contribute to opening the window in inflammatory conditions suitable for lymphoma development.

In the present study, we showed another role of IL-6 in the survival and subsequent growth transformation of non-neoplastic B cells. This is an important event in the development of B-cell lymphoma. In situ evaluation of human inflammatory lesions in cytokine production, ROS production, and apoptosis of B-lineage cells will further clarify the mechanism of lymphomagenesis with an inflammatory background.

\section{Materials and Methods \\ Cells}

Peripheral blood lymphocytes separated with FicollPaque (Pharmacia, Uppsala, Sweden) from two healthy donors were infected with EBV derived from B95-8 cells (a generous gift from Professor Kenzo Takada, Hokkaido University, Sapporo, Japan), and two LCLs were established, designated OS and TTK, respectively. Cells were grown in RPMI 1640 medium (Nissui, Tokyo, Japan) supplemented with $10 \%$ heatinactivated FCS (Bio Whittaker, Walkersville, Maryland), and collected at $5 \times 10^{5}$ to $1 \times 10^{6}$ cells per milliliter (greater than $95 \%$ viability) for apoptosis experiments and mRNA extraction.

\section{Recombinant Cytokines}

Human recombinant IL-6 $(\mathrm{rlL}-6)\left(5 \times 10^{6} \mathrm{U} / \mathrm{mg}\right.$ protein) and human interferon- $\gamma$ were kindly provided by Ajinomoto Corporation (Tokyo, Japan) and Ohtsuka Pharmaceutical Company (Tokyo, Japan), respectively. Human rlL-10 $\left(5 \times 10^{5} \mathrm{U} / \mathrm{mg}\right.$ protein $)$ was purchased from Genzyme (Cambridge, Massachusetts).

\section{Determination of $\mathrm{H}_{2} \mathrm{O}_{2}$}

The concentration of $\mathrm{H}_{2} \mathrm{O}_{2}$ produced by xanthine (X; ICN Biomedicals Inc., Aurora, Ohio) and xanthine oxidase (XOD; EC 1.1.3.22; Sigma Chemical Company, St. Louis, Missouri) reaction was determined according to the method (Hildebrandt and Roots, 1975) with minor modifications. X/XOD reaction was carried out in a $200 \mu \mathrm{l}$ volume, and equal volume of ice-cold $4 \%$ trichloroacetic acid was added. After incubation on ice for 20 minutes, the tubes were centrifuged, and $200 \mu$ l aliquots of the supernatant fluid were transferred to new tubes, to which $10 \mathrm{~mm}$ ferrous ammonium sulfate $(40 \mu \mathrm{l})$ and $3 \mathrm{~m}$ sodium thiocyanate $(16 \mu l)$ were added. After incubation at room temperature for 10 minutes, the extinction of the $\mathrm{Fe}(\mathrm{SCN})_{3}$ was quantified by measuring $\mathrm{OD}$ at $480 \mathrm{~nm}$ with a spectrophotometer. The standard curve was 
obtained using $\mathrm{H}_{2} \mathrm{O}_{2}$ at known concentrations as samples.

\section{Viability Assay of X/XOD-Treated Cells}

Cells $\left(2 \times 10^{5}\right.$ cell $\left./ \mathrm{ml}\right)$ were cultured with various factors for indicated time periods. After washing twice with serum-free medium, cells $\left(2 \times 10^{4}\right)$ were seeded in 96-well tissue culture plates in $150 \mu$ l of culture medium containing $X$ and XOD at the indicated concentration (Sofuni and Ishidate, 1984). Cells were incubated for 24 hours, at $37^{\circ} \mathrm{C}$, in a humidified $95 \%$ air, $5 \% \mathrm{CO}_{2}$ atmosphere. The viability of cells was measured with trypan blue dye exclusion and the number of viable cells was also estimated by the MTT assay as described previously (Scudiero et al, 1988). As an inhibitor of XOD, 4-hydroxypyrazolo (3, 4-d) pyrimidine (Allopurinol, Sigma) (Shibanuma et al, 1988) was also added to the culture in some experiments.

\section{Detection of DNA Fragmentation}

The extent of DNA fragmentation in X/XOD-treated cells was determined by the method described by Sellins and Cohen (1987) with some modifications. The cell pellet was lysed with lysing buffer (10 mM Tris, 10 mм EDTA, $\mathrm{pH} 7.5$ ) containing $0.5 \%$ Triton $\mathrm{X}-100$, and the lysates were centrifuged. The supernatant, containing fragmented DNA, was incubated with RNase $A$, and further incubated with proteinase $K$. The fragmented DNA was quantified by measuring $\mathrm{OD}_{260}$ and isopropanol-precipitated until use. DNAs were electrophoresed in 1.5\% agarose gels and visualized on ultraviolet transilluminator.

\section{Flow Cytometric Analysis for Apoptotic Cells}

Cells were collected by centrifugation and fixed in suspension with $70 \%$ ethanol, then stored at $-20^{\circ} \mathrm{C}$ for at most 2 days until flow cytometric measurement. The cells were centrifuged at $560 \times g$ for 5 minutes and washed with phosphate buffered saline (PBS). The cell pellets $\left(2-3 \times 10^{6}\right.$ cells) were resuspended in $40 \mu$ of phosphate-citrate buffer $(\mathrm{pH} \mathrm{7.8)}$ at room temperature for 2 hours with occasional vortex mixing (Gong et al, 1994). After centrifugation, $2 \mu \mathrm{g} / \mathrm{ml}$ RNase A were added to the pellet, and the suspensions were incubated at $37^{\circ} \mathrm{C}$ for 30 minutes. After another centrifugation the cells were incubated in $50 \mu \mathrm{g} / \mathrm{ml}$ propidium iodide (Sigma) with PBS and 0.1\% Triton $\mathrm{X}-100$ on ice for 30 minutes, then subjected to flow cytometric measurement. The fluorescence of individual cells was measured with FACS Calibur (Becton Dickinson, San Jose, California). The acquired data were analyzed by ModFit LTV2.0 software (Verity Software House, Inc., Topsham, Maine).

\section{mRNA Extraction and Northern Blot for bcl-2}

Total RNA was extracted from cells by the acid guanidinium-phenol chloroform method. mRNA was purified by using oligodeoxythymidine latex (Takara, Kyoto, Japan), quantified by measuring $\mathrm{OD}_{260}$, and ethanol-precipitated at $-80^{\circ} \mathrm{C}$ until use. Five micrograms of mRNA were electrophoresed in $1 \%$ formaldehyde-agarose gels and Northern blotted as previously described (Kanno et al, 1993). Human bcl-2 DNA probe (Tsujimoto and Croce, 1986) and murine actin DNA probe were kindly provided by Professor Yoshihide Tsujimoto (Osaka University, Suita, Japan) and Dr. Motoo Kitagawa (Chiba University, Chiba, Japan), respectively. These probes were labeled with $\alpha$-[32P]-dCTP by using a random primer DNA labeling kit (Takara). Northern blotted filters were prehybridized, hybridized, and washed as described previously (Kanno et al, 1996) with the exception of an additional 20 minutes washing with $0.1 \times$ SSPE $(15 \mathrm{~mm} \mathrm{NaCl}, 1$ $\mathrm{mm} \mathrm{Na}$ phosphate, $0.1 \mathrm{~mm}$ EDTA), $0.1 \%$ sodium dodecyl sulfate at $70^{\circ} \mathrm{C}$ for actin mRNA, and at $55^{\circ} \mathrm{C}$ for bcl-2 mRNA.

\section{Long Term Culture of X/XOD-Treated Cells}

Cells were passed every 3 days at the cell density of $1 \times 10^{5} \mathrm{cells} / \mathrm{ml}$ or every other day at $2 \times 10^{5} \mathrm{cells} / \mathrm{ml}$ in the medium supplemented with or without $100 \mathrm{U} / \mathrm{ml}$ of human rlL-6. After washing twice with serum-free medium, cells were resuspended in the medium and adjusted to the density of $2 \times 10^{5}$ cells $/ \mathrm{ml}$. Cells $(1 \times$ $10^{6}$ ) were seeded in a $60 \mathrm{~mm}$ tissue culture dish in a 5 $\mathrm{ml}$ of the medium containing $X$ and $X O D$ at the indicated concentrations. Dishes were duplicated for each condition. Cells were incubated for 24 hours, at $37^{\circ} \mathrm{C}$, in a humidified $95 \%$ air, $5 \% \mathrm{CO}_{2}$ atmosphere, then the number of viable cells was estimated by trypan blue dye exclusion test.

\section{Cytogenetic Analysis}

Chromosomal study was performed on samples obtained from the cells by the trypsin-Giemsa banding method. Well-spread metaphases were photographed and arranged according to the recommendations of International System for Human Cytogenetic Nomenclature (1995).

\section{Growth Assay of Cell Lines}

Cells $\left(1 \times 10^{4}\right)$ were seeded in 96-well tissue culture plates in $150 \mu$ l of culture medium supplemented with various concentration of FCS. The plates were prepared in duplicate. One plate was subjected to MTT assay just after preparation, indicating the base line of cell growth (Day 0), and the other was incubated for 72 hours, at $37^{\circ} \mathrm{C}$, in a humidified $95 \%$ air, $5 \% \mathrm{CO}_{2}$ atmosphere; then the number of cells was estimated by MTT assay as described above (Day 3). The growth of the cells was indicated by the proportion of OD at Day 3 to that at Day 0.

\section{Colony Formation in Soft Agar}

Cells were resuspended in RPMI 1640 medium supplemented with $15 \%$ heat-inactivated FCS and $0.16 \%$ (w/v) of purified agarose (GTG agarose; FMC BioProducts, Rockland, Maine) at a density of 67 cells $/ \mathrm{ml}$. 
Aliquots of cell suspension $(1,2$, and $3 \mathrm{ml}$ containing 67,133 , and 200 estimated cells, respectively) were poured into a $60 \mathrm{~mm}$ tissue culture dish containing 5 $\mathrm{ml}$ of gelatin, which consisted of the same medium with the exception of concentration of agarose of $0.25 \%(w / v)$. Dishes were prepared in duplicate in each line. Cultures were scored for colonies at Day 21 after the seeding. Aggregates of at least 50 cells were considered as colonies.

\section{Statistical Analysis}

Statistical significance of differences in the cloning efficiency between the cell lines was estimated by $\chi^{2}$ test; $p<0.05$ was considered significant.

\section{Acknowledgements}

We thank Dr. Shinobu Yamauchi for the preliminary experiments for apoptosis induction, Ms. Izumi Sakaguchi for technical assistance, and Ms. Yumi Kanno for preparing the manuscript.

\section{References}

Akira S, Taga T, and Kishimoto T (1993). Interleukin-6 in biology and medicine. Adv Immunol 54:1-78.

Ando T, Kusugami K, Ohsuga M, Ina K, Shinoda M, Konagaya $\mathrm{T}$, Sakai T, Imada A, Kasuga N, Nada T, Ichiyama S, and Blaser MJ (1998). Differential normalization of mucosal interleukin-8 and interleukin-6 activity after Helicobacter pyIori eradication. Infect Immun 66:4742-4747.

Aozasa K (1992). Malignant lymphoma of the mucosaassociated lymphoid tissue. Am J Surg Pathol 16:90-92.

Banchereau J, De Paoli P, Vallé A, Garcia E, and Rousset F (1991). Long-term human B cell lines dependent on interleukin-4 and antibody to CD40. Science 251:70-72.

Bertoni F, Cazzaniga G, Bosshard G, Roggero E, Barbazza R, De Boni M, Capella C, Pedrinis E, Cavalli F, Biondi A, and Zucca E (1997). Immunoglobulin heavy chain diversity genes rearrangement pattern indicates that MALT-type gastric lymphoma $\mathrm{B}$ cells have undergone an antigen selection process. $\mathrm{Br} J$ Haematol 97:830-836.

Bursch W, Lauer B, Timmermann-Trosiener I, Barthel G, Schuppler J, and Schulte-Hermann R (1984). Controlled death (apoptosis) of normal and putative preneoplastic cells in rat liver following withdrawal of tumor promoters. Carcinogenesis 5:453-458.

Buschle M, Campana D, Carding SR, Richard C, Hoffbrand AV, and Brenner MK (1993). Interferon $\gamma$ inhibits apoptotic cell death in B cell chronic lymphocytic leukemia. J Exp Med 177:213-218.

Carson DA, Seto S, Wasson DB, and Carrera CJ (1986). DNA strand breaks, NAD metabolism, and programmed cell death. Exp Cell Res 164:273-281.

Cerutti PA and Trump BF (1991). Inflammation and oxidative stress in carcinogenesis. Cancer Cells 3:1-7.

Cigudosa JC, Parsa NZ, Louie DC, Filippa DA, Jhanwar SC, Johansson B, Mitelman F, and Chaganti RSK (1999). Cytogenetic analysis of 363 consecutively ascertained diffuse large B-cell lymphomas. Genes Chromosomes Cancer 25: 123-133.
Duell H, Lengfelder E, Fink R, Giesen R, and Bauchinger M (1995). Effect of activated oxygen species in human lymphocytes. Mutat Res 336:29-38.

Fang W, Rivard JJ, Ganser JA, LeBien TW, Nath KA, Mueller $\mathrm{DL}$, and Behrens TW (1995). Bcl- $X_{L}$ rescues WEHI 231 B lymphocytes from oxidant-mediated death following diverse apoptotic stimuli. J Immunol 155:66-75.

Gaidano G and Dalla-Favera R (1993). Biologic and molecular characterization of non-Hodgkin's lymphoma. Curr Opin Oncol 5:776-784.

Glaser R, Theil KS, Bonneau RH, Sheridan JF, Vasquez M, and Allen CM (1993). Spontaneous development of a chromosomal translocation $5 ; 14$ in an Epstein-Barr-virusassociated B-cell lymphoma in a SCID mouse. Int $\mathrm{J}$ Cancer 55:281-287.

Gong J, Traganos F, and Darzynkiewicz Z (1994). A selective procedure for DNA extraction from apoptotic cells applicable for gel electrophoresis and flow cytometry. Anal Biochem 218:314-319.

Greiner A, Knörr C, Qin Y, Sebald W, Schimpl A, Banchereau J, and Müller-Hermelink HK (1997). Low-grade B cell lymphomas of mucosa-associated lymphoid tissue (MALT-type) require CD40-mediated signaling and Th2-type cytokines for in vitro growth and differentiation. Am J Pathol 150:15831593.

Hallas C, Greiner A, Peters K, and Müller-Hermelink HK (1998). Immunoglobulin $V_{H}$ genes of high-grade mucosaassociated lymphoid tissue lymphomas show a high load of somatic mutations and evidence of antigen-dependent affinity maturation. Lab Invest 78:277-287.

Henderson S, Rowe M, Gregory C, Croom-Carter D, Wang F, Longnecker R, Kieff E, and Rickinson A (1991). Induction of bcl-2 expression by Epstein-Barr virus latent membrane protein 1 protects infected B cells from programmed cell death. Cell 65:1107-1115.

Hildebrandt AG and Roots I (1975). Reduced nicotinamide adenine dinucleotide phosphate (NADPH)-dependent formation and breakdown of hydrogen peroxide during mixed function oxidation reactions in liver microsomes. Arch Biochem Biophys 171:385-397.

Hockenbery DM, Oltvai ZN, Yin XM, Milliman CL, and Korsmeyer SJ (1993). Bcl-2 functions in an antioxidant pathway to prevent apoptosis. Cell 75:241-251.

International System for Human Cytogenetic Nomenclature (ISCN) 1995 (1995). Report of the standing committee on human cytogenetic nomenclature. Mitelman F, editor. Basel: S. Karger.

luchi K, Aozasa K, Yamamoto S, Mori T, Tajima K, Minato K, Mukai K, Komatsu H, Tagaki T, Kobashi Y, Yamabe H, and Shimoyama M (1989). Non-Hodgkin's lymphoma of the pleural cavity developing from long-standing pyothorax: Summary of clinical and pathological findings in thirty-seven cases. Jpn J Clin Oncol 19:249-257.

luchi K, Ichimiya A, Akashi A, Mizuta T, Lee YE, Tada H, Mori T, Sawamura K, Lee YS, Furuse K, Yamamoto S, and Aozasa K (1987). Non-Hodgkin's lymphoma of the pleural cavity developing from long-standing pyothorax. Cancer 60:17711775. 
Kanno H, Wolfinbarger JB, and Bloom ME (1993). Aleutian mink disease parvovirus infection of mink peritoneal macrophages and human macrophage cell lines. J Virol 67:20752082.

Kanno H, Yasunaga Y, Ohsawa M, Taniwaki M, luchi K, Naka N, Torikai K, Shimoyama M, and Aozasa K (1996). Expression of Epstein-Barr virus latent infection genes and oncogenes in lymphoma cell lines derived from pyothorax-associated lymphoma. Int J Cancer 67:86-94.

Kato I, Tajima K, Suchi T, Aozasa K, Matsuzuka F, Kuma K, and Tominaga $S$ (1985). Chronic thyroiditis as a risk factor of B-cell lymphoma in the thyroid gland. Jpn $\mathrm{J}$ Cancer Res 76:1085-1090.

Kellogg III EW and Fridovich I (1975). Superoxide, hydrogen peroxide, and singlet oxygen in lipid peroxidation by a xanthine oxidase system. J Biol Chem 250:8812-8817.

Muehlematter D, Larsson R, and Cerutti P (1988). Active oxygen induced DNA strand breakage and poly ADPribosylation in promotable and non-promotable JB6 mouse epidermal cells. Carcinogenesis 9:239-245.

Parsonnet J, Hansen S, Rodriguez L, Gelb AB, Warnke RA, Jellum $\mathrm{E}$, Orentreich $\mathrm{N}$, Vogelman $\mathrm{JH}$, and Friedman GD (1994). Helicobacter pylori infection and gastric lymphoma. N Engl J Med 330:1267-1271.

Phillips BJ, James TEB, and Anderson D (1984). Genetic damage in $\mathrm{CHO}$ cells exposed to enzymically generated active oxygen species. Mutat Res 126:265-271.

Root RK, Metcalf J, Oshino N, and Chance B (1975). $\mathrm{H}_{2} \mathrm{O}_{2}$ release from human granulocytes during phagocytosis: I. Documentation, quantitation, and some regulating factors. J Clin Invest 55:945-955.

Rousset F, Garcia E, Defrance T, Péronne C, Vezzio N, Hsu $\mathrm{DH}$, Kastelein R, Moore KW, and Banchereau J (1992). Interleukin 10 is a potent growth and differentiation factor for activated human B lymphocytes. Proc Natl Acad Sci USA 89:1890-1893.

Rowe M, Young LS, Crocker J, Stokes H, Henderson S, and Rickinson AB (1991). Epstein-Barr virus (EBV)-associated lymphoproliferative disease in the SCID mouse model: Implications for the pathogenesis of EBV-positive lymphomas in man. J Exp Med 173:147-158.

Scala G, Quinto I, Ruocco MR, Arcucci A, Mallardo M, Caretto P, Forni G, and Venuta S (1990). Expression of an exogenous interleukin 6 gene in human Epstein Barr virus $B$ cells confers growth advantage and in vivo tumorigenicity. J Exp Med 172:61-68.

Schraufstätter I, Hyslop PA, Jackson JH, and Cochrane CG (1988). Oxidant-induced DNA damage of target cells. J Clin Invest 82:1040-1050.

Schwarze MM and Hawley RG (1995). Prevention of myeloma cell apoptosis by ectopic $b c l-2$ expression or interleukin 6-mediated up-regulation of $b c l-x_{\mathrm{L}}$. Cancer Res 55:22622265.

Scudiero DA, Shoemaker RH, Paull KD, Monks A, Tierney S, Nofziger TH, Currens MJ, Seniff D, and Boyd MR (1988). Evaluation of a soluble tetrazolium/formazan assay for cell growth and drug sensitivity in culture using human and other tumor cell lines. Cancer Res 48:4827-4833.
Sellins KS and Cohen JJ (1987). Gene induction by $\gamma$-irradiation leads to DNA fragmentation in lymphocytes. J Immunol 139:3199-3206.

Shibanuma M, Kuroki T, and Nose K (1988). Induction of DNA replication and expression of proto-oncogene c-myc and c-fos in quiescent Balb/3T3 cells by xanthine/xanthine oxidase. Oncogene 3:17-21.

Sofuni T and Ishidate Jr M (1984). Induction of chromosomal aberrations in cultured Chinese hamster cells in a superoxide-generating system. Mutat Res 140:27-31.

Suematsu S, Matsuda T, Aozasa K, Akira S, Nakano N, Ohno S, Miyazaki J, Yamamura K, Hirano T, and Kishimoto T (1989). IgG1 plasmacytosis in interleukin-6 transgenic mice. Proc Natl Acad Sci USA 86:7547-7551.

Suematsu S, Matsusaka T, Matsuda T, Ohno S, Miyazaki J, Yamamura K, Hirano T, and Kishimoto T (1992). Generation of plasmacytomas with the chromosomal translocation $\mathrm{t}(12$; $15)$ in interleukin 6 transgenic mice. Proc Natl Acad Sci USA 89:232-235.

Teague TK, Marrack P, Kappler JW, and Vella AT (1997). IL-6 rescues resting mouse $T$ cells from apoptosis. J Immunol 158:5791-5796.

Tosato G, Tanner J, Jones KD, Revel M, and Pike SE (1990). Identification of interleukin-6 as an autocrine growth factor for Epstein-Barr virus-immortalized B cells. J Virol 64:30333041.

Tsujimoto $Y$ and Croce CM (1986). Analysis of the structure, transcripts, and protein products of $b c /-2$, the gene involved in human follicular lymphoma. Proc Natl Acad Sci USA 83:5214-5218.

Weitberg AB, Weitzman SA, Destrempes M, Latt SA, and Stossel TP (1983). Stimulated human phagocytes produce cytogenetic changes in cultured mammalian cells. N Engl J Med 308:26-30.

Weitzman SA, Weitberg AB, Clark EP, and Stossel TP (1985). Phagocytes as carcinogens: Malignant transformation produced by human neutrophils. Science 227:1231-1233.

Whitacre CM and Cathcart MK (1992). Oxygen free radical generation and regulation of proliferative activity of human mononuclear cells responding to different mitogens. Cell Immunol 144:287-295.

Yokoyama A, Maruyama M, Ito M, Kohno N, Hiwada N, and Yano S (1992). Interleukin 6 activity in pleural effusion: Its diagnostic value and thrombopoietic activity. Chest 102: 1055-1059.

Yonish-Rouach E, Resnitzky D, Lotem J, Sachs L, Kimchi A, and Oren M (1991). Wild-type p53 induces apoptosis of myeloid leukemic cells that is inhibited by interleukin-6. Nature 352:345-347.

Zimmerman R and Cerutti P (1984). Active oxygen acts as a promoter of transformation in mouse embryo $\mathrm{C} 3 \mathrm{H} / 10 \mathrm{~T}^{1 / 2}$ / C18 fibroblasts. Proc Natl Acad Sci USA 81:2085-2087. 